\title{
EVALUASI PENGELOLAAN DANA DESA DALAM PEMBANGUNAN FISIK DAN NON FISIK DI KECAMATAN DOKO KELURAHAN BLITAR
}

\author{
*Sri Haryati ${ }^{1)}$, Fauziah Hanum ${ }^{2)}$, Heylen Amildha Yanuarita ${ }^{3)}$ \\ 1) Program Studi Administrasi Publik Fakultas Ilmu Sosial dan Ilmu Politik Universitas Kadiri, \\ Indonesia \\ 2) Program Studi Administrasi Publik Fakultas Ilmu Sosial dan Ilmu Politik Universitas Kadiri, \\ Indonesia \\ 3) Program Studi Administrasi Publik Fakultas Ilmu Sosial dan Ilmu Politik Universitas Kadiri, \\ Indonesia \\ *Email Korespondensi: sriharyati@unik-kediri.ac.id
}

\begin{abstract}
Abstrak
Faktor keuangan atau pendanaan sangat diperlukan didalam setiap aktivitas dalam rangka penyelenggaraan pemerintahan, pelaksanaan pembangunan, pembinaan dan pemberdayaan masyarakat, faktor keuangan desa masih sangat tergantung oleh pemerintah pusat dikarenakan sumber keuangan desa tersebut berasal dari empat sumber yaitu : 1) Dana Desa, 2) Alokasi Dana Desa, 3) Pendapatan Asli Desa dan, 4) Bagi Hasil. Dari empat sumber yang tersebut adalah Dana Desa dan Alokasi Dana Desa. Analisa kemampuan keuangan desa dalam pembiayaan pemerintahan, pelaksanaan pembangunan dan pemberdayaan masyarakat permasalahan yang timbul adalah bagimana desa dalam mengelola dana desa agar penyelenggaraan kegiatan tersebut biasanya berjalan dengan baik dan mencapai hasil yang diharapkan oleh masyarakat. Adapun tujuan dalam penelitian ini untuk mengetahui bagaimana pengelolaan dana desa untuk pembangunan fisik dan non fisik. Sedangkan analisa datanya menggunakan adalah analisis interaktif dari Miles dan Huberman. Hasil penelitian ini adalah pembangunan dana desa untuk pembangunan fisik dan non fisik desa dengan baik sesuai dengan petunjuk pelaksanaan mulai dari pembuatan rencana pelaksanaan dan penyampaian pertanggungjawaban sudah dilaksanakan sesuai aturan dan petunjuk pelaksanaan.
\end{abstract}

Kata Kunci: Evaluasi; Dana Desa; Pendapatan Asli Daerah

\begin{abstract}
Financial factors or funding are needed in every activity in the context of government administration, development implementation, community development, and empowerment, village financial factors are still very dependent on the central government because the village's financial sources come from four sources, namely: 1) Village Fund, 2) Allocation Village Fund, 3) Village Original Income and, 4) Profit Sharing. Of the four sources, the Village Fund and the Village Fund Allocation. Analysis of village financial capacity in government financing, implementation of development, and community empowerment. The problem that arises is how the village manages village funds so that the implementation of these activities usually goes well and achieves the results expected by the community. The purpose of this study was to determine how village funds
\end{abstract}


were managed for physical and non-physical development. While the data analysis used is an interactive analysis from Miles and Huberman. The result of this research is that the development of village funds for physical and non-physical development of the village following the implementation instructions, starting from the making of the implementation plan and the delivery of accountability, has been implemented according to the rules and implementation guidelines.

Keywords: Evaluation; Village Fund; Local Government Revenue

\section{PENDAHULUAN}

Perjalanan ketatanegaraan Negara Kesatuan Republik Indonesia, dewasa ini pemerintah Negara Kesatuan Republik Indonesia menganut system pemerintahan desentralisasi dengan memberikan kesempatan dan kelulasaan kepada daerah untuk menyelenggarakan otonomi daerah. Otonomi daerah dalam pemerintah pusat melimpahkan sebagian kekuasaannya (kewenangannya) kepada daerah. Pemberian kewenangan kepada daerah untuk mengurus dan mengatur kebutuhan masyarakat daerahnya sendiri.

Salah satu kewenangan yang diserahkan kepada daerah adalah pengelolaan keuangan, pengelolaan keuangan daerah tidak hanya dilakukan oleh kabupaten dan kota saja, melainkan termasuk juga desa juga mempunyai kewenangan sendiri dalam mengelola kewenangan mereka sendiri, disampaikan pengelolaan keuangan, desa juga diberi kekuasaan menyelenggarakan pemerintahan dan pembangunan, desa dalam penyelenggaraan pemerintahan, pembangunan dan keuangan diatur dalam UndangUndang Nomor 6 tahun 2014 tentang desa. Penetapan undang-undang tentang desa oleh Pemerintah, memberi kesempatan kepada desa untuk membuat perencanaan anggaran yang sesuai dengan kebutuhan yang mereka perlukan. Undang-undang desa tersebut dibuat dengan tujuan untuk membuat satu landasan yang kuat bagi desa dalam melaksanakan pemerintahan dan pembangunan menuju masyarakat yang adil, makmur, serta sejahtera.

Pemerintah Desa dalam mewujudkan pengelolaan keuangan yang baik, semua pengelolaan keuangan desa harus sesuai dengan Peraturan Menteri Dalam Negeri No. 113 dan 114 tentang keuangan desa. Dimana semua pengelolaan keuangan desa harus berpedoman pada peraturan tersebut. Mengingat dana desa memberikan dampak yang 
besar bagi perkembangan desa, peneliti ingin melihat lebih dalam tentnag dana desa pada aspek pengelolaan, lebih lanjut peneliti ingin melihat Kepala Desa, Ketua RT, Lembaga Desa memaknai pengelolaan dana desa sehingga masalah dalam penelitian ini adalah evaluasi pengelolaan dana desa pada pembangunan fisik dan pemberdanyaan masyarakat non fisik.

\section{TINJAUAN PUSTAKA}

Evaluasi diartikan sebagai suatu proses yang tidak terlepas dari adanya serangkaian tindakan spesifikasi kegiatan yang dapat diukur kemudian dianalisis dengan menggunakan suatu pendekatan yang ilmiah untuk dapat menjadi suatu rekomendasi tentang manfaat dan kegunaan suatu penilaian. Sedangkan menurut (Mindarti \& Muzaqi, 2018) kegiatan evaluasi daapt didefinisikan dengan empat hal 1) Spesifikasi evaluasi yaitu mendefinisikan tujuan dan kriteria dari suatu program atau proses yang dievaluasi, 2) Pengukuran evaluasi yaitu pengumpulan informasi yang relevan dengan obyek evaluasi, 3) Menganalisis yaitu penyerupaan penggunaan keputusan evaluasi untuk memecahkan suatu permasalahan dan, 4) Rekomendasi adalah suatu penilaian terhadap apa yang akan dinilai.

Memahami suatu evaluasi dalam dinamika aktivitas tugas Kepala Desa dalam pengelolaan dana desa tidak bisa dipisahkan dari adanya bentuk evaluasi secara evaluasi secara tehnis, dan evaluasi secara praktis. Ketiga evaluasi tersebut tentu terdapat pada unsur-unsur pedoman pelaksanaan kebijakan dana desa.

Menurut Undang-Undang Republik Indoensia Nomor 6 tahun 2014 Tentang desa yang dimaksud dengan desa adalah "suatu kesatuan masyarakat hukum yang dimiliki batas wilayah yang berwenang untuk emngatur dan mengurus urusan pemerintahan, kepentingan masyarakat setempat berdasarkan prakarsa masyarakat. Asal usul dan/atau hak trardisional yang diukur dan dihormati dalam sistem pemerintahan Negara Republik Indonesia.

Pemerintah desa menurut Undang-Undang Nomor 6 tahun 2014 tentang desa adalah penyelenggaraan urusan pemerintahan dan kepentingan masyarakat setempat dalam sistem pemerintahan Negara Kesatuan Republik Indonesia. Dalam unsur 
penyelenggaraan pemerintahan desa dijalankan oleh pemerintah desa. Pemerintahan desa menurut undang-undang No. 6 tahun 2014 tentang desa pemerintah desa adalah "kepala desa atau yang disebut dengan lain dibantu perangkat desa sebagai unsur penyelenggara pemerintahanan desa, badan musyawarah desa atau disebut dengan nama lain menurut undang-undang No. 6 tahun 2014 tentang desa adalah lembaga yang melaksanakan fungsi pemerintahan yang anggotanya merupakan wakil dari penduduk desa berdasarkan keterwakilan wilayah ditetapkan secara demokrasi."

Menurut undang-undang No. 6 tahun 2014 tentang desa yang dimaksud keuangan desa adalah "semua hak dan kewajiban desa yang dapat dinilai dengan uang serta segala sesuatu berupa uang dan barang yang berhubungan dengan pelaksanaan hak dan kewajiban desa. Hak dan kewajiban desa yang dapat dinilai dengan uang menimbulkan pendapatan, belanja pembiyaan dan pengelolaan keuangan desa.

Berdasarkan Peraturan Menteri Dalam Negeri Nomor 113 tahun 2014 tentang keuangan desa yang dimaksud dengan dana desa adalah "dana yang bersumber dari anggaran pendapatan dan belanja Negara yang diperuntukkan bagi desa, yang ditransfer melalui anggara pendapatan dan belanja daerah Kabupaten/Kota dan digunakan untuk pembiayaan penyelenggaraan pemerintahan, pembangunan, pembinaan kemasyarakatan dan pemberdayaan masyarakat. Dalam penggunaan dana desa yang diterima dari pemerintah pusat maupun dari pemerintah daerah, desa diberi kekuasaan (mandat) untuk mengelola dana desa tersebut sesuai dengan kebutuhan masyarakat. Untuk itu desa dalam penggunaan dana desa tersebut melalui tahapan-tahapan yaitu:

a. Pembuatan perencanaan.

Menurut (Adrimas, 2012) perencanaan dalam arti luas adalah "suatu proses mempersiapkan secara sistematis kegiatan-kegiatan yang akan dilakukan untuk mencapai tujuan tertentu oleh karena itu pada hakekatnya terdapat pada tiap-tiap jenis usaha manusia. Sedang menurut Siagian (2016) memberikan definisi perencanaan sebagai berikut:

Pendapatan desa sebagaimana yang disepakati Undang-undang Republik Indonesia No. 6 tahun 2014 Bab VIII pasal 72 tentang keuangan desa pendapatan desa sebagai mana yang dimaksud dalam pasal 7 ayat 2 bersumber dari : 
1) Pendapatan asli desa terdiri dari hasil usaha, swadaya dan partisipasi, gotongroyong dan lain-lain.

2) Alokasi anggaran dan pendapatan negara.

3) Bagian dari hasil pajak daerah dan retribusi daerah kabupaten/kota dana perimbangan yang diterima kabupaten/kota.

4) Alokasi dana desa yang merupakan bagian dana perimbangan yang diterima kabupaten/kota.

5) Bantuan keuangan dari anggaran pendapatan dan belanja daerah provinsi dan anggaran dan pendapatan dan belanja daerah kabupaten/kota.

6) Hibah dan sumbangan yang tidak mengikat dari pihak ketiga.

7) Dan lain-lain pendapatan desa yang sah.

Peraturan Menteri Dalam Negeri No. 113 tahun 2014 tentang keuangan desa menjelaskan bahwa keuangan desa didapat dari empat sumber dana yaitu:

1) Dana desa

2) Alokasi dana desa

3) Pendapatan asli desa

4) Bagi hasil pengembalian retribusi

Kemudian dari keempat sumber dana tersebut digunakan untuk membuat rencana anggaran pendapatan dan belanja desa (RAPBDes). Sumber terbesar keuangan desa didapat dari desa dan alokasi dana desa "seluruh proses pemikiran dan penentuan secara matang dari pada hal-hal yang akan dikerjakan dimasa yang akan datang dalam rangka pencapaian tujuan yang telah ditentukan.

Berdasarkan pendapat diatas maka dapat disimpulkan bahwa perencanaan pada dasarnya adalah suatu proses penentuan kegiatan yang akan dilaksanakan dalam rangka pencapaian suatu tujuan yang telah ditetapkan dengan menghitung sumber-sumber yang ada. Pelaksanaan penggunaan dana desa dalam pembangunan perencanaan sangat penting untuk dilakukan dengan alasan yaitu :

1) Keterbatasan sumber-sumber yang ada baik aspek kualitas personal, anggaran, peralatan, maupun jangka waktu. 
2) Memberikan arahan pedoman dalam pelaksanaan kegiatan seperti menunjukkan kegiatan seperti menunjukkan sekala prioritas kegiatan dalam pencapaian tujuan.

3) Dengan adanya perencaan, maka aka nada alat ukur atau standar ukur untuk melakukan pengawasan.

Adapun dalam proses perencanaan, penggunaan dana desa untuk pembangunan, kepala desa selaku pimpinan pemerintahan desa harus dapat membina hubungan yang harmonis, baik dengan perangkat desa maupun lembaga-lembaga desa yang ada dalam proses perencanaan agar pembangunan desa dapat dilaksanakan dengan baik dan mencapai hasil sesuai yang diinginkan. Dari sini maka dapat diketahui bahwa pada dasarnya perencaan pengelolaan dana desa itu mencakup:

1) Adanya sasaran tujuan rencana

2) Aktivitas kegiatan

3) Hasil yang harus dicapai

b. Menjalankan/pelaksanaan

Pelaksanaan perencaan adalah setiap langkah yang berkaitan dengan pelaksanaan perencanaan menurut (Abidin, 2012) mendefinisikan implementasi/pelaksanaan kebijakan adalah "tindakan-tindakan yang dilakukan baik oleh individu atau pejabatpejabat atau kelompok-kelompok pemerintah atau swasta diarahkan tercapainya tujuatujuan yang telah ditetapkan dalam keputusan kebijakan”.

Berdasarkan definisi diatas apabila kita hubungkan dengan perencanaan penggunaan dana desa dalam pembangunan, yang sudah ditetapkan oleh perangkat serta panitia pengelolaan dana desa. Untuk mengukur pelaksanaan perencanaan penggunaan dana desa dan pembangunan kita kan menggunakan teori (Alfian, 2018). Adapun untuk mengukur implementasi (pelaksanaan kebijakan ada tiga pertanyaan)

1) Sampai dimana pejabat-pejabat pelaksana konsistensi dengan keputusan kebijakan.

2) Sejauh mana tujuan kebijakan tercapai

3) Faktor-faktor apa saja yang secara langsung mempengaruhi output dan dampak kebijakan 


\section{c. Pertanggungjawaban}

Setelah pemerintah desa mendapatkan bantuan dana desa baik dari pusat maupun dari pemerintah daerah kabupaten/kota selanjutnya pemerintah desa akan menindaklanjuti dengan menggunakan dana desa untuk pembiyaan pemerintahan, pembangunan pembinaan dan pemberdayaan masyarakat, mulai dari perencanaan, pelaksanaan dan terakir perangkat desa dituntut dan wajib membuat/menyajikan laporan pertanggungjawaban terhadap penggunaan dana desa yang sudah diterima oleh desa. Pembuatan pertanggungjawaban dalam penggunaan dana desa harus sesuai dengan aturan

1) Pertanggungjawaban per semester tiap tahun.

2) Pertanggungjawaban pada akhir proyek seusai dengan perda kabuapten.

Pembangunan kawasan pedesaan ditujukan untuk meningkatkan kesejahteraan masyarakat desa, oleh karena itu pemerintah desa mempunyai peranan yang sangat penting dan strategis, karena posisi pemerintah desa dalam pembangunan nasional menduduki posisi yang amat penting, karena masyarakat sebagai pelaku utama pembangunan dan pemerintah berkewajiban untuk membana, melindungi agar desa menjadi kuat, maju, mendiri dan demokrasi. (Muzaqi et al., 2020) Sehingga dapat menciptakan landasan yang kuat dalam melaksanakan pembangunan baik fisik maupun non fisik serta melaksanakan pemerintahan menuju masyarakat yang adil, makmur dan sejahtera menurut Siagian (2016) pembangunan didefinisikan "suatu usaha untuk rangkaian yang berencana dan dilakukan secara sadar oleh suatu bangsa, negara, dan pemerintah menuju modernisasi dalam pembinaan bangsa". Menurut undang-undang tentang desa no. 6 tahun 2014 pembangunan desa adalah "upaya peningkatkan kualitas kehidupan untuk sebesar-besarnya kesejahteraan masyarakat desa”. Jadi pembangunan desa merupakan proses yang menyeluruh dalam arti bahwa pembangunan desa meliputi pembangunan fisik dan pembangunan non fisik meliputi 1) pembinaan masyarakat, dan 2) pembedayaan masyarakat.

\section{METODE PENELITIAN}

Berangkat dari judul penelitian Evaluasi pengelolaan dana desa dalam pembangunan fisik dan non fisik desa pada penelitian ini peneliti mengunakan jenis 
penelitian fenomenologi dengan pendekatan kualitatif. Penelitian fenomenologi ini didasarkan pada pengalaman orang lain dengan mempelajari bentuk-bentuk pengalaman dan sudut padang orang yang mengalaminya. Secara langsung, seolah-olah kita mengalaminya, dalam penelitian ini yang menjadi informasi (subyek penelitian) adalah perangkat desa, lembaga-lembaga desa, ketua RT, ketua RW, masyarakat desa. Sumberdata dalam penelitian ini. Data primfer dan data sekunder, prosedur/tehnik pengumpulan data menggunakan wawancara, observasi dan dokumentasi. Analisa data yang digunakan adalah analisis interaktif dari Miles dan Huberman dalam (Saldana, 2014) yang menggunakan tiga komponen pokok yaitu :

1. Pengumpulan data

2. Reduksi data

3. Sajian data

4. Penarikan kesimpulan

Metode analisis data yang digunakan adalah pattern metting (pencocokan atau penjodohan data membandingkan pola yang didasarkan atas empiris yang dipridiksi (Yin, 2011) artinya aktifitas yang mencoba melakukan perbandingan antara data empiris yang diperoleh dengan suatu pola, konsep atau tehnik yang telah ditentukan. Tempat penelitian di Kecamatan Doko, Kabupaten Blitar.

\section{HASIL DAN PEMBAHASAN}

Dana Desa merupakan dana yang bersumber dari anggaran pendapatan dan belanja negara yang diperuntukkan bagi desa yang ditransfer melalui anggaran pendapatan dan belanja daerah kabupaten/kota dan digunakan untuk membiayai penyelenggaraan pemerintah pelaksanaan pembangunan, pembinaan kemasyarakatan dan pemberdayaan masyarakat dengan tujuan untuk membuat suatu landasan yang kuat dalam melaksanakan pemerintahan dan pembangunan menuju masyarakat yang adil, makmur dan sejahtera. Berdasarkan hasil penelitian menunjukkan bahwa pengelolaan dana desa terbagi menjadi dua (2) pengelolaan yaitu pengelolaan pembangunan fisik dan pengelolaan pemberdayaan masyarakat.

\section{a. Pengelolaan Pembangunan Fisik}


Dalam pengelolaan pembangunan fisik akan kita lihat dari:

1) Pembuatan Perencanaan

Dalam rangka pembuatan perencanaan penggunaan dana desa untuk pembangunan desa. Desa-desa di Kecamatan Doko, Kabupaten Blitar berdasarkan hasil penelitian menunjukkan bahwa dalam pembuatan perencanaan penggunaan dana desa untuk pembangunan fisik menggunakan perencanaan partisipatif dengan menggunakan pendekatan bottom up yaitu pendekatan pembangunan tradisional yang uncemental yaitu hanya menambah atau mengurangi jumlah rupiah pada item-item yang sudah ada sebelumnya dengan menggunakan data tahun sebelumnya. Sebagai dasar untuk menyesuaikan besarnya penambahan atau pengurangan tanpa dilakukan kajian yang mendalam (Mardiasmo, 2016) dan sistem penyusunan anggaran dengan sistem ini tidak pernah ada kritik dari masyarakat dan sudah dirasa tepat.

2) Pelaksanaan

Realisasi pembangunan fisik desa ditentukan oleh Tim Pengelola Kegiatan (TPK) yang dibentuk oleh kepada desa. Tim pengelola kegiatan dengan menggunakan unsur perangkat desa, lembaga desa dan tokoh masyarakat. Tugas dari TPK mengelola realisasi semua pembangunan fisik desa mulai dari pengadaan barang dan jasa serta membuat laporan akhir kegiatan dan SPJ

Pengelolaan realisasi pembangunan yang dilakukan oleh TPK kurang transparan, karena dalam pengelolaannya TPK tidak pernah menginformasikan pembangunan yang akan dilaksanakan sehingga ketua RT sebagai symbol perwakilan masyarakat menjadi tidak tampak.

3) Pembuatan Pertanggungjawaban

Dalam menyampaikan laporan pertanggungjawaban penggunaan dana desa untuk pembangunan fisik desa dilakukan oleh tim pengelolaan kegiatan (TPK) yang diketuai oleh dua orang ini sudah sesuai dengan Perda Kabupaten Blitar. Setiap proyek yang dikerjakan sudah selesai TPK harus membuat laporan akhir kegiatan SPJ yang disampaikan kepada panitia penerima hasil pembangunan.

b. Pemberdayaan Masyarakat (Pembangunan Non Fisik)

1) Perencanaan 
Penentuan program pemberdayaan masyarakat selama ini difokuskan untuk penjualan selama ini difokuskan untuk penguatan lembaga-lembaga desa, sehingga tidak sesuai dengan kebutuhan masyarakat yang menginginkan pemberdayaan masyarakat untuk sesuatu yang menimbulkan usaha seperti pelatihan, pelestarian lingkungan desa, pemberdayaan masyarakat selama ini tidak sesuai dengan program pemberdayaan masyarakat, partisipasi program pemberdayaan masyarakat dalam perencanaan pemberdayaan masayrakat merupakan pastisipasi semua, kehadiran masyarakat dalam rapat perencanaan cukup tinggi tetpi masyarakat bersifat reatif, kehadiran masyarakat dalam perencanaan untuk mendengarkan pemaparan pemerintah desa tentang programprogram yang akan dilaksanakan.

Hal ini berakibat pelatihan-pelatihan yang telah dilakukan selama ini belum menunjukkan adanya kemajuan bagi masyararkat, selain itu pelatihan yang sudah dilaksanakan tidak dibina dengan baik, sehingga masyarakat yang sudah memiliki bekal dari pelatihan tersebut lebihmemilih kebijakan luar kota

2) Pelaksanaan

Pelaksanaan pemberdayaan masyarakat tidak suistanability dan tidak ada kontribusi ekonomi bagi pemerintah desa. Suistainability adalah laporan non keuangan seperti informasi aktivitas usaha dan perkembangan usaha tidak adanya suistainability dan kontribusi ekonomi menunjukkan bahwa dana desa untuk pemberdayaan masyarakat sebagai wujud kegiatan dari kepala desa. Dimana tidak ada tolak ukur keberlanjutan dari suatu pemberdayaan yang dilakukan oleh pemerintah desa.

3) Laporan Pertanggungjawaban

Dalam suatu pelaksanaan kegiatan, baik yang menggunakan dana maupun tidak maka diharuskan pelaksana melakukan kegiatan yang berupa pertanggungjawaban tak terkecuali pada satu kegiatan pemberdayaan masyarakat yang dilakukan di Desa, Kecamatan Doko, Kabupaten Blitar, untuk kegiatan pertanggungjawaban ini karena tida adanya tolak ukur dalam bentuk laporan dari penerima dan pemberdayaan kepada pemerintah desa, maka pemerintah desa tidak dapat mengetahui usaha tersebut berkembangatau tidak. 


\section{KESIMPULAN}

Berdasarkan data hasil penelitian yang sudah peneliti paparkan diatas menunjukkan bahwa pengelolaan dana desa terbagi menjadi dua yaitu pengelolaan pembangunan non fisik dan pemberdayaan masyarakat, untuk itu dapat peneliti simpulkan sebagai berikut :

a. Dilihat dari perencanaan penggunaan dana desa

Pengelolaan dana desa untuk pembangunan fisik dan pemberdayaan masyarakat dalam pembuatan perencanaannya menggunakan perencanaan partisipatif dengan pendekatan Bottom-up. Partisipasi masyarakat dalam perencanaan penggunaan dana desa tingkat partisipasinya tinggi dan masyarakat cukup aktif, kecuali dalam perencanaan pemberdayaan masyarakat partisipasi tinggi tapi sifat masyarakat reaktif, tetapi partisipasi masayrakat disini adalah partisipasi semua karena keikutsertaan masyarakat sebatas perencanaan untuk selanjutnya masyarakat tidak mengetahui.

b. Dilihat dari pelaksanaan

Untuk pelaksanaan program pembangunan pemerintah desa membentuk tim pengelolaan kegiatan menggunakan untuk perangkat desa lembaga desa dan tokoh masyarakat tugas TPK mengelola realisasi semua pembangunan fisik desa mulai dari pengadaan barang dan jasa. Ruang lingkup kerja TPK luas pengelolaan realisasi pembangunan yang dilakukan oleh TPK kurang transparan, karena dalam pengelolaanya TPK tidak pernah menginformasikan pembangunan yang akan dibangun.

c. Pembuatan Laporan

Dalam pembuatan laporan akhir kegiatan karena realisasi pembangunan ditentukan oleh tim pengelola kegiatan yang mempunyai tugas mengelola realisasi semua pembangunan mulai dari pengadaan barang dan jasa maka yang mempunyai kewajiban untuk membuat pelaporan/SPJ adalah tim pengelola kegiatan pada panitia penerima hasil pembangunan. Pertanggungjawaban yang dilakukan TPK melalui surat pertanggungjawaban (SPJ) dan bukti fisif.

Berdasarkan hasil penelitian, pembahasan serta kesimpulan yang telah dikemukakan diatas berikut ini adalah beberapa saran yang diharapkan dapat menjadi masukan dan bagi pemerintahan desa dan masyarakat desa dalam mengelola dana desa. 
a. Bagi kepala desa, diharapkan kepala desa lebih transparan pada pelaksanaan realisasipembangunan agar masyarakat ikut berperan aktif mengawasi dan mengawal pengelolaan dana desa.

b. Bagi kepala desa meskipun pendekatan bottom-up dalam perencanaan sudah sangat baik, namun kualitas aspirasi perlu ditingkatkan agar partisipasi masyarakat tidak hanya sebagai simbol ligimitas birokrasi kepala desa.

\section{REFERENSI}

Abidin, S. Z. 2012. Kebijakan Publik. Jakarta : Salemba Humanika.

Adrimas. 2012. Perencanaan Pembangunan Ekonomi. Andalas University.

Alfian, F. D. 2018. The Policy Model Strategy For The Development Of SME Batik Blimbing Malang Using A Balanced Scorecard Method. Eurasia: Economics \& Business, 10(16), 31-38.

Mindarti, L. I., \& Muzaqi, A. H. 2018. Micro, Small, And Medium Enterprises (Msmes) Empowerment Through Quadruplehelix Approach (A Study At Department Of Micro Enterprise Cooperatives And Trade In Batu City). Journal Ilmu Sosial, Politik, Dan Ilmu Pemerintahan, 7(2), 1-13.

Muzaqi, A. H., Pratama, M. R., \& Widodo, S. 2020. Strategi Peningkatan Kesejahteraan Sosial Penyandang Disabilitas Netra Melalui Kebijakan Ingklusif. Journal Publicuho, 3(3), 381-393.

Peraturan Menteri Dalam Negeri Nomor 113 Tahun 2014. Tentang Keuangan Desa.

Peraturan Pemerintah No. 60 Tahun 2014. Tentang Dana Desa Bersumber dari Anggaran Pendapatan dan Belanja Daerah.

Peraturan Pemerintah No. 43 Tahun 2014. Tentang Pelaksanaan UU No. 06.

Saldana. 2014. Qualitative Data Analysis, A Methods Sourcebook. UI-Press.

Siagian, Sondang. 2016. Sistem Informasi Manajemen. Jakarta: Bumi Aksara

Undang-undang Nomor 6 Tahun 2014. Tentang Desa.

Undang Undang Nomor. 22 Tahun 1999.Tentang Otonomi Daerah.

Yin, R. K. 2011. Qualitative Research from Start to Finish. The Guilford Press. 